\title{
ANALISIS TEKNIK PENILAIAN SIKAP SOSIAL SISWA DALAM PENERAPAN KURIKULUM 2013 DI SDN 1 WATULIMO
}

\author{
Shintia Kandita Tiara ${ }^{1}$, Eka Yuliana Sari ${ }^{2}$ \\ STKIP PGRI Tulungagung
}

\begin{abstract}
The 2013 curriculum that has begun to be piloted in the academic year 2013-2014 requires teachers to assess all aspects of development. These aspects are aspects of attitude, knowledge and skills. Assessment of these three aspects must be done by the teacher himself. Assessment of student attitudes that are also considered important in education Curriculum 2013 is divided into two types of penialaian, namely spiritual attitudes and social attitudes. The purpose of this study is to find out how the technique of assessing students' social attitudes in the application of Curriculum 2013 at SDN 1 Watulimo District Watulimo Trenggalek Regency academic year 2017 2018. This research is a qualitative research with data collection method of observation, interview and documentary study. This method is used to obtain data of social attitude assessment techniques conducted by teachers. Instrument used in the form of observation sheet of learning activities conducted by teachers and interview sheets with open answer. The results showed that there are three stages of assessment conducted by the teacher, namely the planning, implementation, and reporting of students' social attitude. In accordance with the guidebook of students' social attitudes assessment Curriculum 2013 mentioned that there are four techniques of assessment of social attitudes are obsrvasi, journals, assessment of friends and self-assessment. In the school studied it was found that schools use only two types of assessment techniques, namely observations and journals.
\end{abstract}

Keyword: Curriculum 2013, Social Attitude,; Assessment Technique

\begin{abstract}
Abstrak: : Kurikulum 2013 yang sudah mulai diujicobakan pada tahun ajaran 2013-2014 menuntut guru untuk melakukan penilaian pada semua aspek perkembangan. Aspek tersebut ialah aspek sikap, pengetahuan dan keterampilan. Penilaian ketiga aspek ini harus dilakukan oleh guru itu sendiri. Penilaian sikap siswa yang juga dianggap penting dalam pendidikan Kurikulum 2013 dibagi menjadi dua jenis penialaian, yaitu sikap spiritual dan sikap sosial. Tujuan dari penelitian ini adalah untuk mengetahui bagaimana teknik penilaian sikap sosial siswa dalam penerapan Kurikulum 2013 di SDN 1 Watulimo Kecamatan Watulimo Kabupaten Trenggalek tahun ajaran 2017-2018. Penelitian ini merupakan penelitian Kualitatif dengan metode pengumpulan data observasi, wawancara dan studi dokumenter. Metode ini digunakan untuk memperoleh data teknik penilaian sikap sosial yang dilakukan oleh guru. Instrument yang digunakan berupa lembar observasi kegiatan pembelajaran yang dilakukan oleh guru dan lembar wawancara dengan jawaban terbuka. Hasil penelitian menunjukkan bahwa terdapat tiga tahapan penilaian yang dilakukan oleh guru, yaitu tahap perencanaan, pelaksanaan, dan pelaporan penilaian sikap sosial siswa. Sesuai dengan buku panduan penilaian sikap sosial siswa Kurikulum 2013 disebutkan bahwa ada empat teknik penilaian sikap sosial yaitu obsrvasi, jurnal, penilaian antarteman dan penilaian diri. Pada sekolah yang diteliti ditemukan bahwa sekolah hanya menggunakan dua jenis teknik penilaian, yaitu observasi dan jurnal. Kata Kunci: Kurikulum 2013, Sikap Sosial, Teknik penilaian
\end{abstract}

\section{PENDAHULUAN}

Pendidikan merupakan suatu hal yang penting bagi berkembangnya suatu Negara. Melalui pendidikan yang baik, maka akan melahirkan generasi- generasi yang baik pula untuk negaranya. Proses pendidikan di Indonesia sudah cukup baik, namun pemerintah masih tetap berusaha untuk mengembangkannya. Pendidikan tidak hanya tentang ilmu pengetahuan,

\footnotetext{
I STKIP PGRI Tulungagung, email: shintiawgh27国gmail.com

2 STKIP PGRI Tulungagung
} 
melainkan juga tentang pembentukan karakter atau sikap siswa. Banyak sekali usaha yang dilakukan pemerintah Indonesia untuk memajukan pendidikannya. Salah satunya yaitu dengan membuat Kurikulum baru. Kurikulum merupakan perangkat pendidikan yang harus ada dalam proses pendidikan.

Kurikulum merupakan inti dari proses pendidikan, sebab di antara bidangbidang pendidikan yaitu manajemen pendidikan, kurikulum, pembelajaran, dan bimbingan siswa, kurikulum pengajaran merupakan bidang yang paling langsung berpengaruh terhadap hasil pendidikan. Pengembangan kurikulum, minimal dapat dibedakan antara desain kurikulum atau kurikulum tertulis ("design, written, ideal, intended, official, formal curriculum") dan implementasi kurikulum atau kurikulum perbuatan ("curriculum implementation, actual curriculum, real curriculum, atau curriculum in action") (Sukmadinata \& Syaodih, 2014 ).

Kurikulum terbaru yang dibuat oleh pemerintah yaitu kurikulum 2013. Kurikulum ini merupakan pengembangan dari kurikulum sebelumnya. Kurikulum 2013 merupakan kurikulum baru yang mulai diterapkan pada tahun pelajaran 2013/2014. Kurikulum ini adalah pengembangan dari kurikulum yang telah ada sebelumnya, baik Kurikulum Berbasis Kompetensi yang telah dirintis pada tahun 2004 maupun Kurikulum Tingkat Satuan Pendidikan pada tahun 2006. Hanya saja yang menjadi titik tekan pada Kurikulum 2013 ini adalah adanya peningkatan dan keseimbangan soft skills dan hard skills yang meliputi aspek kompetensi sikap, keterampilan dan pengetahuan. Kemudian, kedudukan kompetensi yang semula diturunkan dari mata pelajaran berubah menjadi mata pelajaran dikembangkan dari kompetensi. Selain itu, pembelajaran lebih bersifat tematik integrative dalam semua mata pelajaran. Dengan demikian dapat dipahami bahwa Kurikulum 2013 adalah sebuah kurikulum yang dikembangkan untuk meningkatkan dan menyeimbangkan kemampuan soft skills dan hard skill yang berupa sikap, keterampilan dan pengetahuan (Fadlillah, 2014, hal.16).

Proses pembelajaran merupakan hal utama dalam pendidikan, namun tidak kalah pentingnya dengan proses penilaian. Kegiatan pembelajaran yang dilakukan harus dinilai agar dapat diketahui hasil dari pembelajaran yang telah dilakukan. Penilaian pembelajaran dilakukan oleh guru kelas dan guru mata pelajaran secara langsung. Seperti yang telah dikemukakan diatas bahwa Kurikulum 2013 mengembangkan aspek sikap, pengetahuan dan keterampilan, sehingga untuk penilaiannya juga mencakup tiga aspek tersebut.

Gronlund \& Linn (1990, hal.5) seperti yang dikutip di Kusaeri (2014, hal.16) mendefinisikan penilaian sebagai suatu proses yang sistematis dan mencakup kegiatan mengumpulkan, menganalisis, serta menginterpretasikan informasi untuk menentukan seberapa jauh seorang atau sekeompok siswa mencapai tujuan pembelajaran yang telah ditetapkan, baik aspek pengetahuan, sikap maupun keterampilan, sehingga dapat disimpulkan bahwa penilaian adalah suatu prosedur sistematis yang mencakup kegiatan mengumpulkan, menganalisis, dan menginterpretasikan informasi yang dapat digunakan untuk membuat kesimpulan tentang karakteristik seseorang atau objek.

$$
\text { Penilaian kurikulum harus }
$$
mencakup aspek pengetahuan, keterampilan dan sikap secara utuh dan proporsional, sesuai dengan kompetensi inti yang telah ditentukan. Penilaian aspek pengetahuan, dapat dilakukan dengan ujian tulis, lisan, dan daftar isian pertanyaan. Penilaian aspek keterampilan dapat dapat dialkukan dengan dengan ujian praktek, analisis keterampilan dan analisis tugas, serta penialian oleh siswa sendiri. Adapun penilaian sikap, dapat dilakukan dengan daftar isian sikap (pengamatan pribadi) dari diri sendiri, dan daftar isian sikap yang disesuaikan dengan kompetensi inti (Mulyasa, 2014, hlm.137). 
Kurikulum 2013 juga disebut sebagai Pendidikan Karakter. Dimana pengembangan karakter siswa merupakan hal yang sama pentingnya dengan pengembangan pengetahuan siswa. Setiap siswa tentunya memiliki sikap yang berbeda-beda. Diharapkan dari setiap kegiatan pembelajaran yang telah dilakukan dapat mengembangkan sikap siswa.

Beberapa guru Sekolah Dasar masih merasa kebingungan dalam menilai sikap siswa, terutama pada sikap sosial. Guru merasa kesulitan menilai sikap sosial siswa dikarenakan begitu banyaknya jenis sikap sosial yang harus dinilai. Selain itu, proses penilain yang begitu banyak juga dirasa merepotkan guru. Sebagian guru juga masih belum memahami bagaimana teknik penilaian sikap yang sesuai dengan Kurikulum 2013. Padahal guru-guru tersebut sudah mengikuti pelatihan Kurikulum 2013.

Berdasarkan paparan di atas, tujuan penelitian ini adalah untuk mengetahui teknik penilaian sikap sosial siswa yang dilakukan oleh guru dalam penerepan Kurikulum 2013 di SDN 1 Watulimo Kecamatan Watulimo Kabupaten Trenggalek tahun ajaran 2017-2018. Diharapkan dari adanya penelitian ini dapat memberikan informasi baru bagi pembaca pada umumnya dan bagi guru pada khusunya.

\section{TINJUAN PUSTAKA \\ Kurikulum 2013}

Kurikulum 2013 merupakan kurikulum baru yang mulai diterapkan pada tahun pelajaran 2013/2014. Kurikulum ini adalah pengembangan dari kurikulum yang telah ada sebelumnya, baik Kurikulum Berbasis Kompetensi yang telah dirintis pada tahun 2004 maupun Kurikulum Tingat Satuan Pendidikan pada tahun 2006. Hanya saja yang menjadi titik tekan pada Kurikulum 2013 ini adalah adanya peningkatan dan keseimbangan soft skills dan hard skills yang meliputi aspek kompetensi sikap, keterampilan dan pengetahuan. Kedudukan kompetensi yang semula diturunkan dari mata pelajaran berubah menjadi mata pelajaran dikembangkan dari kompetensi. Selain itu, pembelajaran lebih bersifat tematik integrative dalam semua mata pelajaran. Demikian dapat dipahami bahwa Kurikulum 2013 adalah sebuah kurikulum yang dikembangkan untuk meningkatkan dan menyeimbangkan kemampuan soft skills dan hard skill yang berupa sikap, keterampilan dan pengetahuan (Fadlillah, 2014).

\section{Penilaian}

Gronlund \& Linn (1990) seperti yang dikutip di Kusaeri (2014) mendefinisikan penilaian sebagai suatu proses yang sistematis dan mencakup kegiatan mengumpulkan, menganalisis, serta menginterpretasikan informasi untuk menentukan seberapa jauh seorang atau sekeompok siswa mencapai tujuan pembelajaran yang telah ditetapkan, baik aspek pengetahuan, sikap maupun keterampilan, sehingga dapat disimpulkan bahwa penilaian adalah suatu prosedur sistematis yang mencakup kegiatan mengumpulkan, menganalisis, dan menginterpretasikan informasi yang dapat digunakan untuk membuat kesimpulan tentang karakteristik seseorang atau objek. Ridwan Abdullah Sani (2016) mengungkapkan bahwa penilaian adalah sistematik dan sistemik yang dilakukan melalui pengumpulan data atau informasi yang sahih (valid) dan reliabel dan selanjutnya data atau informasi tersebut diolah sebagai upaya melakukan pertimbangan untuk pengambilan kebijakan suatu program pendidikan.

\section{Sikap Sosial}

Abu Ahmadi (2007) mengungkapkan bahwa "sikap sosial adalah kesadaran individu yang menentukan perbuatan yang nyata, yang berulang-ulang terhadap objek sosial. Sikap sosial dinyatakan tidak oleh seorang saja 
tetapi diperhatikan oleh orang-orang sekelompoknya. Objeknya adalah objek sosial (objeknya banyak orang dalam kelompok) dan dinyatakan berulangulang”. W.A.Gerungan (2009) juga mengungkapkan bahwa suatu attitude sosial dinyatakan dengan cara-cara kegiatan yang sama dan berulang-ulang terhadap objek sosial. Attitude sosial menyebabkan terjadinya cara-cara tingkah laku yang dinyatakan berulang-ulang terhadap suatu objek sosial dan biasanya attitude sosial dinyatakan tidak hanya oleh seseorang, tetapi juga oleh orang lain yang sekelompok atau semasyarakat.

Sikap sosial merupakan ekspresi atau tindakan seseorang dalam menyikapi sesuatu dalam kehidupan sosial. Terdapat subjek dan objek dalam sikap sosial. Sikap seseorang selalu berhubungan dengan kehidupan sosial, karena dengan adanya interaksi sosial akan terlihat sikap seseorang tersebut. Sikap sosial berkembang dalam suatu kelompok sosial yang dinyatakan dengan cara yang sama dan dilakukan berulang-ulang.

\section{Penilaian Sikap Sosial}

Sikap merupakan sebuah ekspresi dari nilai-nilai atau pandangan hidup yang dimiliki oleh seseorang. Sikap dapat dibentuk, sehingga terjadi perilaku atau tindakan yang diinginkan. Kompetensi sikap yang dimaksud dalam panduan ini adalah ekspresi nilai-nilai atau pandangan hidup yang dimiliki oleh seseorang dan diwujudkan dalam perilaku (Imas Kurinasih dan Berlin Sani, 2014). Kurikulum 2013 membagi kompetensi sikap menjadi dua yaitu:

a. Sikap spiritual yang terkait dengan pembentukan siswa yang beriman dan bertakwa.

b. Sikap sosial yang terkait dengan pembentukan siswa yang berakhlak mulia, mandiri, demokratis dan bertanggung jawab.

Penilaian sikap atau karakter siswa dimaksudkan untuk mendeteksi karakter yang terbentuk daam diri siswa melalui pembelajaran yang telah diikutinya. Pembentukan karakter memang tidak bisa sim salabim atau terbentuk dalam waktu singkat, tapi indikator perilaku dapat dideteksi secara dini oleh setiap guru. Teknik penilaian sikap atau karakter siswa dapat dilakukan dengan membuat format penilaian terlebih dahulu. Format tersebut dapat dikembangkan sesuai dengan karakter yang akan dinilai, dan jenis penilaian yang digunakan (Mulyasa, 2014).

Teknik maupun instrumen penilaian sikap spiritual dan sosial hampir sama, namun indikator pencapaian kompetensi sikap sosial lebih banyak daripada indikator pencapaian kompetensi sikap spiritual. Pendidik melakukan penilaian kompetensi sikap melalui observasi, penilaian diri, penilaian teman sejawat (peer evaluation) oleh siswa dan jurnal. Instrument yang digunakan untuk observasi, penilaian diri dan penilaian antar siswa adalah daftar cek atau skala penilaian (ratting scale) yang disertai rubrik, sedangkan pada jurnal berupa catatan pendidik. Penilaian sikap berhubungan dengan sikap siswa terhadap materi pelajaran, sikap siswa terhadap guru/pengajar, sikap siswa terhadap proses pembelajaran, dan sikap yang berkaitan dengan nilai atau norma yang berhubungan dengan materi pemebelajaran (Fadlillah, 2014).

Imas Kurinasih dan Berlin Sani (2014) mengungkapkan bahwa aspek sikap dapat dinilai dengan cara berikut.

a. Observasi

Merupakan teknik penilaian yang dilakukan secara berkesinambungan dengan menggunakan indera, baik secara langsung maupun tidak langsung dengan menggunakan format observasi yang berisi sejumlah indikator perilaku yang diamati. Hal ini juga dilakukan saat pembelajaran maupun diluar pembelajaran.

b. Penilaian Diri

Merupakan teknik penilaian dengan cara meminta siswa untuk mengemukakan kelebihan dan 
kekurangan dirinya dalam konteks pencapaian kompetensi. Instrumen yang digunakan berupa lembar penilaian diri.

c. Penilaian Antar Teman

Merupakan teknik penilaian dengan cara meminta siswa untuk saling menilai terkait dengan sikap dan perilaku keseharian siswa. Instrument yang digunakan berupa lembar penilaian antar siswa.l

d. Jurnal

Merupakan catatan pendidik di dalam dan di luar kelas yang berisi informasi hasil pengamatan tentang kekuatan dan kelemahan siswa yang berkaitan dengan sikap dan perilaku.

\section{METODOLOGI PENELITIAN}

Penelitian dilakasanakan di SDN 1 Watulimo pada tahun ajaran 2017-2018. Penelitian ini akan mengamati teknik penilaian sikap sosial siswa yang dilakukan oleh guru pada saat kegiatan pembelajaran maupun di luar kegiatan pembelajaran. Penelitian ini termasuk dalam jenis penelitian kualitatif yang bersifat deskriptif, karena penelitian ini menggambarkan, melukiskan atau mendeskripsikan variabel teknik penilaian sikap sosial siswa sekolah dasar di SDN 1 Watulimo Kecamatan Watulimo Kabupaten Trenggalek. Prosedur penelitian ini melalui tiga tahapan penelitian. Adapun prosedur penelitian yang akan dilakukan oleh peneliti yaitu tahap pralapangan, tahap pekerjaan lapangan dan tahap analisis data (Moleong, 2014, hal.127-151). Subjek dalam penelitian ini adalah teknik penilaian sikap sosial yang dilakukan oleh guru di SDN 1 Watulimo. Peneliti meneliti guru kelas III sebagai sampel kelas rendah dan guru kelas $\mathrm{V}$ sebagai sampel kelas tinggi. Penelitian ini dilaksanakan pada saat kegiatan pembelajaran dan setelah kegiatan pembelajaran.

Instrument utama dalam penelitian ini adalah peneliti. Adapun instrument yang berada diluar peneliti yaitu pedoman observasi, pedoman wawancara dan dokumentasi. Sesuai dengan instrument penelitian yang di ungkapkan maka teknik penelitian yang dilakukan yaitu wawancara, observasi, dan studi dokumenter. Observasi dilakukan untuk memperoleh data dari guru melalui pengamatan langsung terhadap kegiatan guru dalam menilai sikap sosial siswa. Wawancara dilakukan untuk memperoleh data secara langsung dari pihak guru. Sebelum melaksanakan observasi dan wawancara, peneliti membuat pedoman untuk observasi dan wawancara terlebih dahulu untuk membatasi topik yang akan dibahas. Terdapat tiga indikator yang akan diteliti dalam penelitian ini. Indikator tersebut yaitu perencanaan penilaian sikap sosial siswa, pelaksanaan penilaian sikap sosial siswa dan pelaporan penilaian sikap sosial siswa.

Proses analisis data di lapangan menggunakan Model Miles and Huberman. Miles and Huberman (1984) seperti yang dikutip di Sugiyono (2011, hal.337) mengemukakan bahwa aktivitas dalam analisis data kualitatif dilakukan secara interaktif dan berlangsung secara terus menerus sampai tuntas, sehingga datanya sudah jenuh. Aktivitas yang dilakukan dalam analisis data yaitu data reduction (Reduksi data), data display dan conclution drawing/ verification. Pengecekan keabsahan data menggunakan teknik triangulasi. Teknik ini digunakan agar data yang diperoleh mendapat derajat serta kepastian.

\section{HASIL PENELITIAN DAN PEMBAHASAN}

Kurikulum 2013 sudah mulai diuji cobakan mulai tahun ajaran 2013-2014. Mulai tahun itulah SDN 1 Watulimo menjadi salah satu sekolah yang menerapkan uji coba penerapan Kurikulum 2013. Awal uji coba diterapkan yaitu pada kelas 1 dan kelas 4. SDN 1 Watulimo merupakan salah satu sekolah terbaik di Kecamatan Watulimo, sehingga sekolah tersebut ditunjuk oleh Dinas Pendidikan setempat untuk melakukan uji coba 
Kurikulum 2013. Hingga saat ini SDN 1 Watulimo sudah menggunakan Kurikulum 2013 pada kelas 1 sampai kelas 6 .

Hasil penelitian melalui kegiatan wawancara dan observasi terhadap perencanaan penilaian sikap sosial yang dilakukan oleh guru di SDN 1 Watulimo menunjukkan bahwa guru kelas V dan III sama-sama menyiapkan instrument penilaian sikap sosial sebelum kegiatan pembelajaran. Kedua guru juga menyampaikan indikator sikap sosial yang harus dicapai siswa, namun guru tidak menyampaikan secara langsung, melainkan melalui arahan untuk melakukan sikap yang baik. Acuan guru dalam melakukan penilaian sikap sosial yaitu dari buku paket pegangan siswa dan buku paket pegangan guru. Acuan dari buku paket siswa yaitu sesuai dengan kegiatan pembelajaran pada buku paket siswa. Acuan dari buku paket guru berupa panduan dan contoh instrument penilaian sikap sosial.

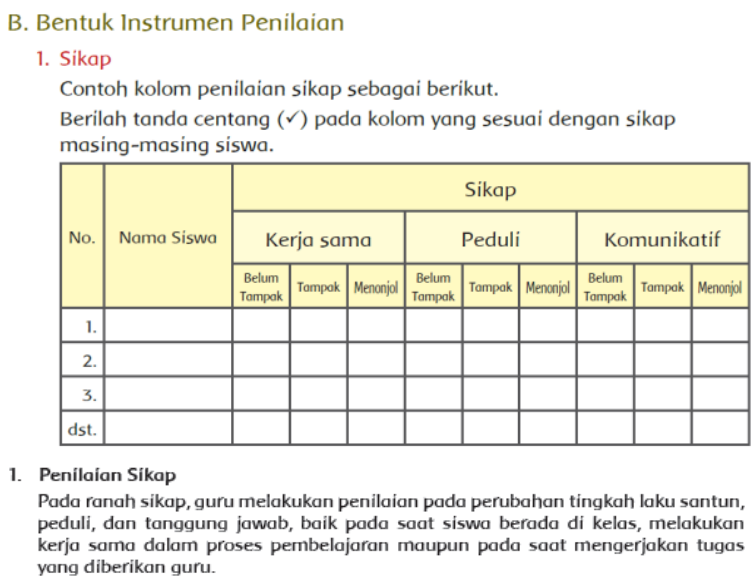

Pada ranah sikap, guru melakukan penilaian pada perubahan tingkah laku santun, peduli, dan tanggung jawab, baik pada saat siswa berada di kelas, melakukan kerja sama dalam proses permbelajaran maupun pada saat mengerjakan tugas yang diberikan guru.

Gambar 1. Instrument penilaian sikap sosial siswa pada buku paket pegangan guru kelas V Tema 9

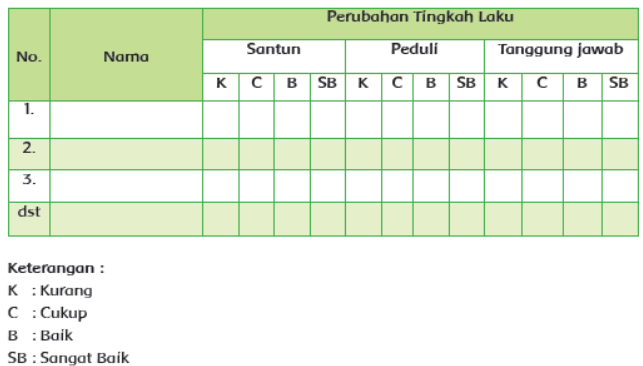

Gambar 2. Instrument penialian sikap sosial pada buku paket pegangan guru kelas III Tema 8

Terdapat perbedaan hasil dari kegiatan wawancara antara guru kelas $\mathrm{V}$ dan guru kelas III. Guru kelas V menyampaikan bahwa beliau tidak menentukan indikator sikap sosial yang akan dinilainya pada setiap harinya, sedangkan guru kelas III menyampaikan bahwa beliau menentukan indikator sikap sosial yang akan dinilai setiap harinya sesuai dengan buku paket pegangan guru. Sejalan dengan hasil dokumentasi peneliti tentang perencanaan penilaian sikap sosial siswa guru juga memiliki dokumen penilaian observasi yang tergabung dalam RPP, serta jurnal sikap sosial siswa yang dibukukan sendiri.

Pelaksanaan penilaian sikap sosial harus dilakukan oleh guru itu sendiri. Guru kelas yang setiap hari bersama siswa tentunya akan lebih mudah dalam melakukan penilaian sikap sosial siswanya. Pelaksanaan penilaian sikap sosial harus dilakukan oleh guru setiap hari dan setiap saat guru melihat perkembangan sikap sosial setiap siswanya. Direktorat Pembinaan Sekolah Dasar (2016, hal.28) mengungkapkan "pelaksanaan penilaian sikap disesuaikan dengan pendekatan pembelajaran yang dilakukan pada saat pembelajaran dan di luar pembelajaran". 


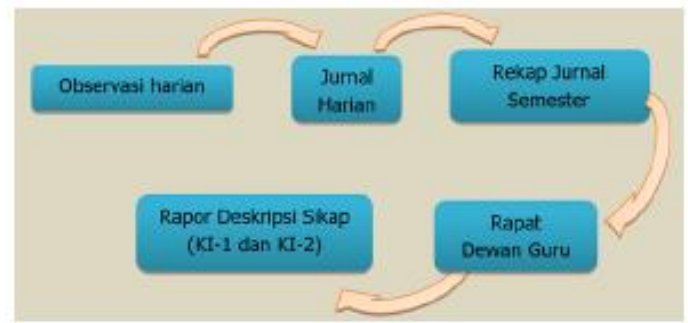

Gambar 3. Alur Pelaksanaan, Pengelolaan dan Pelaporan Penilaian Sikap sesui dengan buku Panduan Penilaian Untuk Sekolah Dasar

Hasil wawancara dan observasi dari kelas V dan III SDN 1 Watulimo mengenai pelaksanaan penilaian sikap sosial yaitu kedua guru sama-sama melakukan penilaian terhadap sikap siswa, termasuk sikap sosial siswa juga dinilai oleh guru. Penilaian sikap sosial siswa dilakukan guru pada saat kegiatan pembelajaran dan di luar kegiatan pembelajaran. Guru kelas V tidak menentukan indikator sikap sosial apa saja yang akan dinilai setiap harinya, namun berbeda dengan guru kelas III mengungkapkan bahwa beliau menentukan indikator sikap sosial yang akan dinilaianya sesuai dengan buku paket pegangan guru dan buku paket pegangan siswa. Teknik penilaian sikap sosial yang dilakukan oleh guru yaitu dengan observasi dan jurnal. Observasi dilakukan guru dengan cara memberi tanda cek/centang pada instrument penilaian yang sudah dibuat guru, sedangkan jurnal diisi oleh guru setiap ada sikap siswa yang dirasa perlu dan penting untuk dicatat. Sejalan dengan hasil dokumentasi peneliti tentang pelaksanaan penilaian sikap sosial siswa guru juga menunjukkan dokumen penilaian observasi yang tergabung dalam RPP yang sudah diisi oleh guru, serta jurnal sikap sosial siswa yang dibukukan sendiri.

Pelaporan mengenai sikap sosial siswa tidak kalah penting dari proses perencanaan dan pelaksanaan penilaian sikap sosial. Pelaporan dilakukan oleh guru pada siswa itu sendiri dan juga pada orang tua siswa atau wali siswa. Hasil wawancara dan observasi dari kelas V dan III SDN 1 Watulimo mengenai pelaporan penilaian sikap sosial yaitu kedua guru sama-sama melakukan pelaporan penilaian sikap sosial siswa secara langsung pada siswa yang bersangkutan dan juga melakukan pelaporan pada orangtua. Pada kegiatan wawancara bersama guru kelas $\mathrm{V}$ dan guru kelas III beliau mengungkapkan untuk pelaporan sikap sosial siswa yang penting, guru memberikan surat pemberitahuan pada orangtua. Pelaporan sikap sosial siswa yang sudah pasti yaitu pada raport siswa. Sejalan dengan hasil dokumentasi peneliti tentang pelaporan penilaian sikap sosial siswa guru juga memiliki dokumen pelaporan sikap sosial siswa. Dokumen ini merupakan raport siswa yang dibagikan setiap semester.

Kurikulum 2013 menekankan pendidikan pada pengembangan dan penyetaraan antara soft skill dan hard skill melalui pengembangan kompetensi pengetahuan, ketrampilan dan sikap. Sejalan dengan yang diungkapkan Fadlillah (2014, hal.16) Kurikulum 2013 adalah sebuah kurikulum yang dikembangkan untuk meningkatkan dan menyeimbangkan kemampuan soft skill dan hard skill yang berupa sikap, ketrampilan dan pengetahuan. Pendidikan Sekolah Dasar merupakan jenjang pendidikan yang sangat terlihat perubahnnya dari pada penerapan Kurikulum 2013. Berbeda dengan Kurikulum Tingkat Satuan Pendidikan, materi pembelajaran pada Kurikulum 2013 dipadukan menjadi satu dalam sebuah Tema. Satu tahun pembelajaran bisa mencapai 8 sampai 9 tema untuk setiap kelasnya. Setiap kompetensi dijelaskan pada Kompetensi Inti setiap tema. Kompetensi Inti satu menjelaskan tentang sikap spiritual yang harus dicapai siswa. Kompetensi Inti dua menjelaskan tentang sikap sosial yang harus dicapai siswa. Kompetensi Inti tiga menjelaskan tentang pengetahuan yang harus dicapai siswa. Kompetensi Inti empat menjelaskan tentang ketrampilan yang harus dicapai siswa. Keempat Kompetensi Inti ini harus dicapai dalam setiap kegiatan pembelajaran.

Ketercapaian keempat Kompetensi Inti ini tidak lepas dari peran seorang guru. 
Seorang guru harus bisa memberikan penilaian yang sesuai dengan keadaan siswa di sekolah. Guru memerlukan teknik maupun instrument penilaian yang sesuai agar dapat memudahkan guru dalam melakukan penilaian. Menurut Kementrian Pendidikan dan Kebudayaan (2013, hal.5) "karakteristik penilaian dalam Kurikulum 2013 yaitu belajar tuntas, otentik, berkesinambungan, menggunakan teknik penilaian yang bervariasi dan berdasarkan acuan kriteria".

Penilaian dalam Kurikulum 2013 mengacu pada Permendikbud Nomor 66 Tahun 2013 seperti yang dikutip di Kunandar (2014, hal.35) tentang Standar Penilaian bertujuan untuk menjamin: (1) perencanaan penilaian siswa sesuai dengan kompetensi yang akan dicapai dan berdasarkan prinsip-prinsip penilaian, (2) pelaksanaan penilaian siswa secara professional,terbuka, edukatif, efektif, efisien, dan sesuai dengan konteks sosial budaya, dan (3) pelaporan hasil penilaian secara objektif, akuntabel, dan informatif. Hal ini sejalan dengan penelitian yang dilakuakan oleh peneliti mengenai teknik penilaian sikap sosial siswa dalam penerapan Kurikulum 2013. Peneliti melakukan penelitian bagaimana guru merencanakan penilaian, melaksanakan penilaian dan melakukan pelaporan dari hasil penilaiannya.

Hasil penilaian sikap sosial di SDN 1 Watulimo direkap oleh pendidik minimal dua kali dalam satu semester yaitu pada mid semester dan pada setiap semester. Hasil penilaian sikap ini akan dibahas dan dilaporkan dalam bentuk deskripsi nilai sikap sosial peserta didik. Langkah-langkah untuk membuat deskripsi nilai sikap selama satu semester yaitu (a)Guru kelas dan guru mata pelajaran mengelompokkan atau menandai catatan-catatan sikap peserta didik yang dituliskan dalam jurnal sikap sosial, (b)Guru kelas membuat rekapitulasi sikap dalam jangka waktu satu semester (jangka waktu bisa disesuaikan sesuai pertimbangan satuan pendidikan), (c)Guru kelas mengumpulkan catatan sikap berupa deskripsi singkat dari guru mata pelajaran (PJOK dan Agama) dan warga sekolah (guru ekstrakurikuler, petugas perpustakaan, petugas kebersihan dan penjaga sekolah), (d)Guru kelas menyimpulkan dan merumuskan deskripsi capaian sikap spiritual dan sosial setiap peserta didik, (e)Deskripsi sikap menggunakan kalimat yang bersifat memotivasi dengan pilihan kata/frasa yang bernada positif. Hindari frasa yang bermakna kontras, misalnya: ... tetapi masih perlu peningkatan dalam ... atau ... namun masih perlu bimbingan dalam hal ... (f)Deskripsi sikap menyebutkan perkembangan sikap peserta didik yang sangat baik, baik, cukup, atau perlu bimbingan, (g)Apabila peserta didik tidak memiliki catatan apapun dalam jurnal, sikap dan perilaku peserta didik tersebut diasumsikan baik, (h)Karena sikap dan perilaku dikembangkan selama satu semester, deskripsi nilai sikap peserta didik dirumuskan pada akhir semester. Oleh karena itu, guru mata pelajaran dan guru kelas harus memeriksa jurnal secara keseluruhan hingga akhir semester untuk menganalisis catatan yang menunjukkan perkembangan sikap dan perilaku peserta didik, (i)Penetapan deskripsi akhir sikap peserta didik dilakukan melalui rapat dewan guru pada akhir semester.

Hasil observasi dan wawancara yang dilakukan oleh peneliti dapat disimpulkan bahwa teknik penilaian sikap sosial yang dilakukan guru disekolah dapat dikatakan sudah cukup baik. Guru melakukan dua jenis teknik penilaian yaitu teknik observasi dan jurnal. Hal ini sejalan dengan pendapat Fadlillah (2014, hal. 201) "pendidik melakukan penilaian kompetensi sikap melalui observasi, penilaian diri, penilaian teman sejawat (peer evaluation) oleh peserta didik dan jurnal". Guru di SDN 1 Watulimo sudah menggunakan dua jenis penilaian yang disebutkan Fadlillah di atas. Walaupun belum semua jenis penilaian digunakan, hal ini sudah lebih baik dari penelitian terdahulu yang dilakukan oleh Darmansyah (2014, hal.17) "Teknik 
penilaian sikap membutuhkan perhatian khusus dari para guru, karena pada kurikulum sebelumnya belum dilakukan. Guru perlu pendalaman melalui pelatihanpelatihan yang memadai agar objektivitas penilaian dapat dilakukan secara optimal". Penelitian lain yang dilakukan oleh Pande Putu Cahya Mega Sanjiwana, Kt. Pudjawan dan I Gd. Margunayasa mengungkapkan "program yang dilakukan dalam mengembangkan sikap sosial yaitu pembelajaran berkelompok, kendala yang ditemukan dalam mengembangkan sikap sosial yaitu siswa mengganggu teman saat proses pembelajaran. guru disarankan agar lebih mengoptimalkan pembelajaran dengan kurikulum 2013 untuk lebih mematangkan pembentukan sikap sosial”.

\section{KESIMPULAN}

Kurikulum 2013 tingkat Sekolah Dasar mulai diterapkan pada tahun ajaran 2013-2014. SDN 1 Watulimo menjadi salah satu sekolah yang menerapkan Kurikulum 2013 pada tahun itu. Pemberlakuan Kurikulum 2013 mengharuskan semua guru merubah cara belajar dari KTSP menjadi pembelajaran Kurikulum 2013 yang disusun dengan adanya tema. Terdapat tiga jenis aspek penilaian yang harus dilakukan guru pada Kurikulum 2013, yaitu penilaian sikap, pengetahuan dan keterampilan. Tidak ada yang lebih unggul, semua penilaian ini harus dilakukan dan dikembangkan oleh guru. Penilaian sikap dibagi menjadi dua jenis, yaitu penilaian sikap spiritual dan penilaian sikap sosial. Kedua jenis penilaian ini memiliki teknik yang sama, namun pada penilaian sikap sosial, jenis sikap sosial yang dinilai lebih banyak dan beragam. Sesuai dengan buku panduan penilaian Kurikulum 2013 disebutkan adanya empat teknik penilaian sikap sosial yang bisa digunakan oleh guru. Empat teknik tersebut yaitu observasi, jurnal, penilaian antar teman dan penilaian diri.

Berdasarkan hasil penelitian dan pembahasan yang telah dilakukan, dapat disimpulkan bahwa teknik penilaian sikap sosial siswa dalam penerapan Kurikulum 2013 yang dilakukan di SDN 1 Watulimo yaitu terdapat dua jenis teknik penilaian sikap sosial yang dilakukan oleh guru. Teknik penilaian tersebut yaitu observasi dan jurnal. Penggunaan teknik penilaian tersebut dibagi dalam tiga tahapan yaitu tahap perencanaan, pelaksanaan dan pelaporan. Berdasarkan hasil penelitian yang dilakukan oleh peneliti, guru tidak merasa kesulitan dalam menerapkan penilaian sikap sosial siswa.

\section{DAFTAR PUSTAKA}

Ahmadi, Abu. (2007). Psikologi Sosial. Jakarta: Rineka Cipta

Direktorat Pembinaan Sekolah Dasar. (2013). Panduan Teknis Penilaian di Sekolah Dasar. Jakarta: Kementrian Pendidikan dan Kebudayaan.

Direktorat Pembinaan Sekolah Dasar, (2016). Panduan Penilaian untuk Sekolah Dasar (SD). Jakarta: Kementrian Pendidikan dan Kebudayaan.

Fadlillah. (2014). Implementasi Kurikulum 2013. Yogyakarta: Arr-Ruzz Media.

Kementerian Pendidikan dan Kebudayaan. (2015). Tema 8 Bumi dan Alam Semesta: Buku Guru SD/MI Kelas 3. Jakarta: Kementerian Pendidikan dan Kebudayaan.

Kementerian Pendidikan dan Kebudayaan, (2017). Tema 9 Benda-Benda di Sekitar Kita: Buku Guru SD/MI Kelas 5 Edisi Revisi. Jakarta: Kementerian Pendidikan dan Kebudayaan.

Kunandar. (2014). Penilaian Autentik (Penilaian Hasil Belajar Peserta Didik Berdasarkan Kurikulum 2013). Jakarta: Raja Grafindo Persada.

Kusaeri. (2014). Acuan dan Teknik Penilaian Proses dan Hasil Belajar dalam Kurikulum 2013. Yogyakarta: Arr-Ruzz Media. 
Moleong, Lexy J. (2014). Metodologi Penelitian Kualitatif. Bandung: Remaja Rosdakarya.

Mulyasa. (2014). Pengembangan dan Implementasi Kurikulum 2013. Bandung: Remaja Rosdakarya.

Sani, Ridwan Abdullah. (2016). Penilaian Autentik. Jakarta: Bumi Aksara.

Sanjiwana, Pande Putu Cahya Mega dkk (2015). Kutipan: Analisis Sikap Sosial Siswa Kelas V Pada Pembelajaran dengan Kurikulum 2013, 3(1). Diperoleh dari https://googleweblight.com/?lite_url =https://ejournal. undiksha.ac.id/index.php/JJPGSD/ar ticle/view/5631\&ei

Sugiyono. (2011). Metode Penelitian Pendidikan. Bandung: Alfabeta.

Sukmadinata, Nana \& Syaodih, Erliany. (2014). Kurikulum dan Pembelajaran Kompetensi. Bandung: Refika Aditama. 